\title{
Stability Assessment for Selection of Elite Sugarcane Clones Across Multi-Environment Based on AMMI and GGE- Biplot Models
}

Eid M Mehareb ( $\sim$ elmoharb@yahoo.com )

Agricultural Research Center https://orcid.org/0000-0001-9481-0482

M.A.M. Osman

Agricultural Research Center

A.E Attia

Agricultural Research Center

M.A. Bekheet

Agricultural Research Center

Abo Elenen FM Fouz

Agricultural Research Center

\section{Research Article}

Keywords: sugarcane, stability, GGE-biplot AMMI, ASV, Cultivar Superiority index,

Posted Date: February 21st, 2022

DOI: https://doi.org/10.21203/rs.3.rs-1297001/v1

License: (9) This work is licensed under a Creative Commons Attribution 4.0 International License.

Read Full License 


\section{Abstract}

Seven field experiments were conducted at three experiment stations representing major sugarcane producing regions in Egypt. Each experiment comprised a randomized complete block design with three replications. Fourteen elite breeding lines typical of those routinely generated in the three final selection stages of sugarcane breeding programs in Egypt, along with one check variety (GT54-9) were evaluated for cane and sugar yield in this study during the 2018/2019, 2019/2020 and 2020/2021 seasons. Stability parameters including cultivar stability rank and superiority index were determined. The data was also investigated using GGE-biplots, the additive main effects and multiplicative interaction model (AMMI), and the AMMI stability value (ASV). The genotype main effect was used to visualize the $\mathrm{G} \times \mathrm{E}$ interaction. The results of these trials are of significance in guiding the selection and recommendation of superior sugarcane varieties and more stable in sugarcane production zones. The clone G.2016-129 had a mean sugar yield and cultivar superiority index for sugar yield exceeding that of GT54-9, and hence was recommended for commercial planting. Because of local conditions in Egypt, an elite sugarcane variety would have high and stable yield and would adapt to a wide range of environments. In the present study, only one clone G.2016-129 fit that definition by producing higher and more stable sugar yield than the commercial variety GT 54-9.. At the side of multivariate analyses, the ASV (AMMI stability value) supports selection of stable varieties in the AMMI Method. Varieties with lowest ASV are stable. Therefore, the results of this study exposed that G.2016-95, F-150 and G.2016-129 with lowest ASV for cane yield by contrast, G.2009-11, G.2016-128, F-150 and G.2016-95 with lowest ASV for sugar yield, were stable clones for cane and sugar yields, respectively

\section{Introduction}

Sugarcane (Saccharum spp. hybrids) is a major cash and industrial crop in Egypt. It has been planted since $641 \mathrm{AD}$, following the introduction of the crop by the Arabs. Sugarcane is presently planted along the Nile River, from Shandaweel station (Sohag governorate) ((latitude of $2633^{\circ} \mathrm{N}$, longitude of $3141^{\circ} \mathrm{E}$ and altitude of $69 \mathrm{~m}$ above sea level) to Kom Ombo station (Aswan governorate) (24.46_ $\mathrm{N}$ and longitude of 32.93_E). The last decade has seen significant advancements in the local breeding and selection programs in Egypt with current commercial cultivars originating from local programs. Local programs now conduct the whole range of activities necessary for variety development including controlled hybridization, early clonal selection and testing through to the final varietal testing stage in multiple locations(1)

Sugarcane varietal selection from a series of different environments trials can be considered as a multicharacteristic selection in which the yields in multi- environments are synonymous with characters. As such an analysis of the data combined over various environments should be conducted so as to form selection index (2).

Stability and adaptability are main criteria for selection for genotype in any breeding program (3). Adapted and stable varieties with high yield potential are identified throughout multi-location trials. 
Nevertheless, breeders invariably encounter genotype $x$ environment interactions (GEI) when evaluating varieties over several of environments, which complicates response of the selection. It is important to quantify GEl in order to design selection methods which can accurately recognize superior cultivars in the final selection stages and predict their potential performance in numerous environments. The cultivar superiority index and stability measurements (4; 5), AMMI (Additive main effects and multiplicative interaction) $(6 ; 7)$ and GGE (genotype and genotype by environment) biplot analysis $(8 ; 9)$ techniques are the most commonly used multivariate approaches to analyse is data collected from multi-environment trials.

The GGE-biplot and AMMI models can be used to support the stability and superiority indices in recognizing varieties with both specific and broad adaptation (10).Multi-environment trials are important for proper ranking of candidate cultivars and to recognize representative selection or production environments (11).This could accelerate breeding efficiency (12) and strengthen the competitiveness of seed production over developed yield (13).

Cultivar superiority index is an alternative tool for assessing mean performance and stability simultaneously (5). The cultivar superiority index defined as the mean square difference between a cultivar's observed value and the best variety within a given environment. This index can be a powerful tool for breeders to selection new sugarcane colons. (Comment: need to discuss what a superior variety is a bit more. For example, are you after a high yielding variety with high stability, OR, maybe you could be after varieties that perform particularly well at each individual site instead of overall stable yield. Etc. These options depend on whether you are chasing broad adaptation or specific adaptation.)

Thus, the main objectives of this study were to

1. Determine the cane and sugar yield stability of studied genotypes using different stability measures and compare those stability statistics from trials conducted across seven test environments.

2. Identify new sugarcane genotypes with stable and high cane and sugar yield for release and registration through selection indices and cultivar superiority index by the AMMI and GGE-biplot models.

\section{Materials And Methods}

\section{Experimental Materials}

The sugarcane genotypes including 14 elite breeding lines and one check variety GT54-9 at the three final selection stages (Main Experiment, Final Experiment and Demonstration) were used in this study. The genotypes were developed by Sugar Crop Research Institute breeding facilities, Agriculture Research Center (ARC), Egypt during 2018/2019, 2019/2020 and 2020/2021 seasons and could be considered representative of clones typically evaluated in the Egyptian sugarcane breeding program (Table 1 ). 
Table 1. Clones (genotypes) evaluated at final selection stages in the seven environments

\begin{tabular}{llllll}
\hline Code & Clone & Code & Clone & Code & Clone \\
\hline G1 & F-150 & G6 & G.2016-99 & G11 & K.81113 \\
\hline G2 & G.2016-168 & G7 & G.2016-129 & $\mathbf{G 1 2}$ & G.99-80 \\
\hline G3 & G.2016-158 & G8 & G.2016-128 & $\mathbf{G 1 3}$ & G.2005-47 \\
\hline G4 & G.2016-74 & G9 & G.2016-95 & $\mathbf{G 1 4}$ & G.2000-5 \\
\hline G5 & G.2016-62 & $\mathbf{G 1 0}$ & G.2009-11 & $\mathbf{G 1 5}$ & G.T.54-9
\end{tabular}

\section{Experimental Design and growing conditions}

A randomized complete block design with three replications was used in each of the seven experiments. Each experimental plot was $42 \mathrm{~m} 2$ including 6 rows of $7 \mathrm{~m}$ in length and $1.0 \mathrm{~m}$ row spacing.

All field experiments were conducted at three stations for selection trials, extending from southern to middle Egypt, namely Kom Ombo station (Aswan governorate), Shandaweel station (Sohag governorate) and Mattana Station (Luxor governorate. These stations cover the range of the sugarcane production area (Table2). The experiments were planted during March and harvested after twelve months, in all seasons. Irrigation was withheld for one month before harvesting. Other agricultural practices were done following recommended commercial practice for the three regions. the plants were harvested at 12 months after planting for all seasons.

Table 2. Details of the different environments for evaluation of sugarcane genotypes

\begin{tabular}{llllll} 
Environment & Location & Governorate & Latitude & Longitude & Season \\
\hline E 1 & Mattana & Luxor & $25^{\circ} 17^{\prime} \mathrm{N}$, & $32^{\circ} 33^{\prime} \mathrm{E}$ & $2020 / 2021$ \\
\hline E 2 & Mattana & Luxor & $25^{\circ} 17^{\prime} \mathrm{N}$, & $32^{\circ} 33^{\prime} \mathrm{E}$ & $2019 / 2020$ \\
\hline E 3 & Mattana & Luxor & $25^{\circ} 17^{\prime} \mathrm{N}$, & $32^{\circ} 33^{\prime} \mathrm{E}$ & $2018 / 2019$ \\
\hline E 4 & Shandaweel & Sohag & $26^{\circ} 33^{\prime} \mathrm{N}$ & $31^{\circ} 41^{\prime} \mathrm{E}$ & $2020 / 2021$ \\
\hline E 5 & Shandaweel & Sohag & $26^{\circ} 33^{\prime} \mathrm{N}$ & $31^{\circ} 41^{\circ} \mathrm{E}$ & $2019 / 2020$ \\
\hline E 6 & Kom Ombo & Aswan & $24.280 \mathrm{~N}$ & $32.57 \mathrm{o} \mathrm{E}$ & $2020 / 2021$ \\
\hline E 7 & Kom Ombo & Aswan & $24.280 \mathrm{~N}$ & $32.57 \mathrm{o} \mathrm{E}$ & $2019 / 2020$
\end{tabular}




\section{Statistical Analysis}

Analyses of variance were separately carried out as a randomized complete block design (RCBD) for each of the seven environments for the collected data as (14). The Means were compared by the Tukey's test $(p<0.05)$ using the Minitab 14 software.

\section{Stability Analysis and Genotype by Interaction ( $\mathrm{x}$ E)}

The following stability measurements were performed on cane and sugar yields under the seven environments (two locations $\times$ two year plus one location $x$ three years), superiority measure [5], and mean absolute rank difference of varieties on the environment [15]. Additionally, the additive main effects and multiplicative interaction model (AMMI) [16] was applied on the cane and sugar yields. Then the genotype main effect [15] was used to visualize the $G \times E$ interaction.

The ASV is the distance from the coordinate point to the origin in a two- dimensional plot of scores for interaction principal component analysis IPCA1 and IPCA2 scores in the additive means effect and multiplicative interaction model (17). As the IPCA1 score contributes more to the genotype by environment interaction sum of squares, a weighted value is desired. This was estimated for each cultivar and each environment giving to the relative contribution of IPCA1 to IPCA2 as per $(18 ; 19)$. (This paragraph should be written in more detail and made clearer - currently not clear exactly what is meant).

The GGE-biplot (genotype main effect plus $G$ xE interaction) [24] was used to visualize the GEl. All stability and $\mathrm{G} \times \mathrm{E}$ analysis was performed using GeneStat- 18 software program.

Need to add some commentary on how the GGE-biplot is interpreted, for readers unfamiliar with the technique.

(Need to also explain the superiority index)

\section{Results}

\section{Performance of sugarcane genotypes across seven environments}

Table ( 3 and 4) shown the performance of sugarcane genotypes across seven environments, that the genotypes varied significantly in cane and sugar yield, respectively. G2 (G.2016-168) produced the higher value of cane yield of 68.04 and 67.68 ton.acre-1,in E1 and E2 which was $8.9 \%$ and $6.2 \%$ higher than the check variety GT. 54-9 (Table 5). Additionally, G.2016-168 produced a sugar yield of 8.45 and 8.04 ton.acre ${ }^{-1}$, in E1 and E2, respectively, which was $30 \%$ and $20.5 \%$ higher than the check variety GT. 54-9. 
Table3 : Mean performance of cane yield of the studied sugarcane genotypes across seven environment

\begin{tabular}{llllllll}
\hline Genotypes & E1 & E2 & E3 & E4 & E5 & E6 & E7 \\
\hline F-150 (G1) & $57.18 \mathrm{~g}$ & $71.47 \mathrm{~b}$ & $54.53 \mathrm{de}$ & $49.95 \mathrm{fg}$ & $52.00 \mathrm{~cd}$ & $38.55 \mathrm{gh}$ & $43.42 \mathrm{~g}$ \\
\hline G.2016-168 (G2) & $68.04 \mathrm{c}$ & $67.68 \mathrm{c}$ & $48.66 \mathrm{~g}$ & $54.44 \mathrm{c}$ & $45.80 \mathrm{ef}$ & $44.12 \mathrm{e}$ & $45.20 \mathrm{f}$ \\
\hline G.2016-158 (G3) & $58.80 \mathrm{f}$ & $86.73 \mathrm{a}$ & $31.44 \mathrm{k}$ & $52.14 \mathrm{de}$ & $51.00 \mathrm{~d}$ & $47.62 \mathrm{~d}$ & $48.50 \mathrm{de}$ \\
\hline G.2016-74 (G4) & $39.93 \mathrm{j}$ & $70.55 \mathrm{~b}$ & $43.67 \mathrm{i}$ & $44.00 \mathrm{j}$ & $45.00 \mathrm{fg}$ & $60.20 \mathrm{a}$ & $47.50 \mathrm{e}$ \\
\hline G.2016-62 (G5) & $74.36 \mathrm{a}$ & $62.92 \mathrm{~d}$ & $27.84 \mathrm{l}$ & $61.89 \mathrm{a}$ & $51.80 \mathrm{~cd}$ & $37.50 \mathrm{~h}$ & $40.00 \mathrm{~h}$ \\
\hline G.2016-99 (G6) & $71.68 \mathrm{~b}$ & $63.04 \mathrm{~d}$ & $39.75 \mathrm{j}$ & $48.00 \mathrm{~h}$ & $50.60 \mathrm{~d}$ & $52.90 \mathrm{c}$ & $50.00 \mathrm{~cd}$ \\
\hline G.2016-129 (G7) & $66.78 \mathrm{~cd}$ & $60.72 \mathrm{e}$ & $55.50 \mathrm{~d}$ & $57.84 \mathrm{~b}$ & $51.40 \mathrm{~d}$ & $52.10 \mathrm{c}$ & $51.00 \mathrm{bc}$ \\
\hline G.2016-128 (G8) & $65.76 \mathrm{~d}$ & $48.00 \mathrm{i}$ & $53.62 \mathrm{ef}$ & $45.00 \mathrm{ij}$ & $46.80 \mathrm{e}$ & $44.00 \mathrm{e}$ & $43.00 \mathrm{~g}$ \\
\hline G.2016-95 (G9) & $58.18 \mathrm{fg}$ & $58.50 \mathrm{f}$ & $52.27 \mathrm{f}$ & $42.00 \mathrm{k}$ & $43.80 \mathrm{~g}$ & $39.10 \mathrm{~g}$ & $40.00 \mathrm{~h}$ \\
\hline G.2009-11 (G10) & $55.58 \mathrm{~h}$ & $50.70 \mathrm{~h}$ & $54.54 \mathrm{de}$ & $45.98 \mathrm{i}$ & $54.60 \mathrm{~b}$ & $61.53 \mathrm{a}$ & $58.00 \mathrm{a}$ \\
\hline K.81113 (G11) & $38.00 \mathrm{k}$ & $36.74 \mathrm{k}$ & $54.42 \mathrm{de}$ & $43.50 \mathrm{jk}$ & $44.40 \mathrm{fg}$ & $47.86 \mathrm{~d}$ & $48.50 \mathrm{de}$ \\
\hline G.99-80 (G12) & $44.17 \mathrm{i}$ & $43.78 \mathrm{j}$ & $75.23 \mathrm{~b}$ & $49.20 \mathrm{gh}$ & $54.60 \mathrm{~b}$ & $41.00 \mathrm{f}$ & $30.02 \mathrm{i}$ \\
\hline G.2005-47 (G13) & $57.25 \mathrm{~g}$ & $50.50 \mathrm{~h}$ & $67.44 \mathrm{c}$ & $51.16 \mathrm{ef}$ & $58.00 \mathrm{a}$ & $54.82 \mathrm{~b}$ & $52.00 \mathrm{~b}$ \\
\hline G.2000-5 (G14) & $72.22 \mathrm{~b}$ & $54.46 \mathrm{~g}$ & $45.29 \mathrm{~h}$ & $52.00 \mathrm{de}$ & $53.00 \mathrm{c}$ & $53.00 \mathrm{c}$ & $42.50 \mathrm{~g}$ \\
\hline G.T.54-9 (G15) & $62.50 \mathrm{e}$ & $63.70 \mathrm{~d}$ & $80.27 \mathrm{a}$ & $53.05 \mathrm{~cd}$ & $55.40 \mathrm{~b}$ & $55.78 \mathrm{~b}$ & $44.98 \mathrm{f}$
\end{tabular}


Table 4: Mean performance of sugar yield of the studied sugarcane genotypes across seven environment

\begin{tabular}{llllllll}
\hline Genotypes & E1 & E2 & E3 & E4 & E5 & E6 & E7 \\
\hline F-150 (G1) & $6.71 \mathrm{ef}$ & $8.55 \mathrm{a}$ & $6.28 \mathrm{~cd}$ & $6.73 \mathrm{abc}$ & $6.86 \mathrm{a}$ & $4.95 \mathrm{~g}$ & $5.71 \mathrm{bcd}$ \\
\hline G.2016-168 (G2) & $8.45 \mathrm{a}$ & $8.04 \mathrm{a}$ & $6.51 \mathrm{bcd}$ & $6.81 \mathrm{ab}$ & $5.71 \mathrm{bcd}$ & $5.65 \mathrm{ef}$ & $5.81 \mathrm{abcd}$ \\
\hline G.2016-158 (G3) & $6.18 \mathrm{f}$ & $8.62 \mathrm{a}$ & $4.13 \mathrm{e}$ & $6.19 \mathrm{~cd}$ & $5.75 \mathrm{bcd}$ & $6.21 \mathrm{cde}$ & $5.95 \mathrm{abc}$ \\
\hline G.2016-74 (G4) & $3.65 \mathrm{~h}$ & $7.27 \mathrm{~b}$ & $4.05 \mathrm{e}$ & $5.71 \mathrm{de}$ & $4.72 \mathrm{~d}$ & $7.66 \mathrm{a}$ & $6.34 \mathrm{a}$ \\
\hline G.2016-62 (G5) & $6.93 \mathrm{cdef}$ & $5.34 \mathrm{de}$ & $3.86 \mathrm{e}$ & $6.07 \mathrm{~d}$ & $6.29 \mathrm{abc}$ & $3.69 \mathrm{~h}$ & $4.11 \mathrm{~g}$ \\
\hline G.2016-99 (G6) & $7.81 \mathrm{ab}$ & $6.97 \mathrm{~b}$ & $4.60 \mathrm{e}$ & $5.91 \mathrm{~d}$ & $6.15 \mathrm{abc}$ & $5.84 \mathrm{def}$ & $5.61 \mathrm{cde}$ \\
\hline G.2016-129 (G7) & $7.64 \mathrm{abcd}$ & $7.12 \mathrm{~b}$ & $7.75 \mathrm{~b}$ & $6.76 \mathrm{abc}$ & $6.11 \mathrm{abc}$ & $6.32 \mathrm{bcd}$ & $6.22 \mathrm{ab}$ \\
\hline G.2016-128 (G8) & $7.49 \mathrm{bcde}$ & $5.97 \mathrm{c}$ & $6.32 \mathrm{bcd}$ & $5.31 \mathrm{ef}$ & $5.68 \mathrm{bcd}$ & $5.37 \mathrm{fg}$ & $5.32 \mathrm{def}$ \\
\hline G.2016-95 (G9) & $7.74 \mathrm{abc}$ & $7.22 \mathrm{~b}$ & $6.76 \mathrm{bc}$ & $5.21 \mathrm{ef}$ & $5.33 \mathrm{~cd}$ & $4.88 \mathrm{~g}$ & $5.11 \mathrm{ef}$ \\
\hline G.2009-11 (G10) & $6.61 \mathrm{f}$ & $4.77 \mathrm{e}$ & $5.21 \mathrm{de}$ & $4.79 \mathrm{f}$ & $5.22 \mathrm{~cd}$ & $6.59 \mathrm{bc}$ & $6.23 \mathrm{ab}$ \\
\hline K.81113 (G11) & $4.08 \mathrm{~h}$ & $4.04 \mathrm{f}$ & $6.43 \mathrm{bcd}$ & $5.31 \mathrm{ef}$ & $4.95 \mathrm{~d}$ & $5.92 \mathrm{def}$ & $6.01 \mathrm{abc}$ \\
\hline G.99-80 (G12) & $5.31 \mathrm{~g}$ & $4.77 \mathrm{e}$ & $9.66 \mathrm{a}$ & $6.98 \mathrm{a}$ & $6.53 \mathrm{ab}$ & $4.96 \mathrm{~g}$ & $3.94 \mathrm{~g}$ \\
\hline G.2005-47 (G13) & $6.87 \mathrm{def}$ & $5.84 \mathrm{~cd}$ & $7.50 \mathrm{bc}$ & $6.23 \mathrm{bcd}$ & $7.05 \mathrm{a}$ & $6.46 \mathrm{bcd}$ & $6.21 \mathrm{ab}$ \\
\hline G.2000-5 (G14) & $8.01 \mathrm{ab}$ & $5.18 \mathrm{e}$ & $4.47 \mathrm{e}$ & $5.91 \mathrm{~d}$ & $6.71 \mathrm{ab}$ & $5.91 \mathrm{def}$ & $4.81 \mathrm{f}$ \\
\hline G.T.54-9 (G15) & $6.51 \mathrm{f}$ & $6.67 \mathrm{~b}$ & $9.60 \mathrm{a}$ & $6.79 \mathrm{ab}$ & $5.23 \mathrm{~cd}$ & $6.98 \mathrm{~b}$ & $5.48 \mathrm{cde}$
\end{tabular}

\section{Additive main effect and multiplicative interaction (AMMI)}

The combined analysis of variance for cane and sugar yield showed that genotypes (G) contributed $12 \%$ and $17.8 \%$ respectively to the total sum of squares while environments $(E)$ contributed $21.4 \%$ and $8.4 \%$ respectively. GEl contributed to $66.3 \%$ and $73.4 \%$ to the total sum of squares of cane and sugar yield respectively (Table 5). The first and second interaction principal component axis (IPCA1 and IPCA2) were highly significant and accounted for 56.11 and $20.81 \%$ of the sums of squares for cane yield and 44.06 and $28.52 \%$ for sugar yield of the total GEI variation, respectively. The GEI was highly significant implying differential response of genotypes to environments (20). 
Table 5. Additive main effects and multiplicative interaction (AMMI) analysis of variance for cane and sugar yield of studied sugarcane genotypes across seven environments

\begin{tabular}{lllllll}
\hline Source & d.f. & \multicolumn{3}{c}{ M.s. } & \multicolumn{3}{c}{ Explained\% } \\
\cline { 2 - 7 } & Cane yield & Sugar yield & Cane yield & Sugar yield & Cane yield & Sugar yield \\
\hline Genotypes & 14 & 14 & $298.9^{\star *}$ & $5.867^{\star *}$ & 12.11 & 17.18 \\
\hline Environments & 6 & 6 & $1234.1^{\star *}$ & $6.686^{\star *}$ & 21.43 & 8.39 \\
\hline Block & 14 & 14 & $4.1^{\star \star}$ & $0.63^{\star *}$ & 0.16 & 1.84 \\
\hline Interactions & 84 & 84 & $272.6^{\star *}$ & $4.015^{\star *}$ & 66.29 & 73.41 \\
\hline IPCA 1 & 19 & 19 & $676.3^{\star *}$ & $7.823^{\star *}$ & 56.11 & 44.06 \\
\hline IPCA 2 & 17 & 17 & $280.4^{\star *}$ & $5.661^{\star *}$ & 20.81 & 28.52 \\
\hline Residuals & 48 & 48 & $110.1^{\star *}$ & $1.926^{\star *}$ & 23.08 & 27.39
\end{tabular}

An ideal environment (21) and genotype are the one which is on the central circle (Fig.1 and 2). Thus, Fig. 1 and 2 shows the comparison plot for clones, and a model clone is one which is near or at the middle of the concentric circle. Based on this assumption, G7 (G2016-129) was the most ideal clone, with high mean cane, sugar yields and high stability.

The analysis AMMI stability values (ASV) exposed that some sugarcane genotypes have high adaptation; though, most of genotypes have specific adaptability (Table 6?). The ASV values showed variations in cane yield stability among the fifteen sugarcane clones (Table 6). According to (18), a stable cultivar is defined as one with AMMI stability values (ASV) value close to zero. The larger the ASV value, either negative or positive, the more specifically adapted a genotype was to certain environments. A smaller ASV value indicated a more stable genotype across environments (17). Consequently, the genotypes G.2016-95 and F-150 with ASV of 0.54 and 1.48, respectively, in addition to G.2016-129 with ASV of 1.64 were the most stable, while the genotypes such as G.99-80, G.2016-158 and G.2016-62 were the least stable (Table 6). As well as ASV exposed variations in sugar yield stability among the 15 sugarcane genotypes. On the other hand the genotypes G.2009-11, G.2016-128 and G.2016-129 were the most stable for sugar yield. 
Table 6. Means, IPCA scores and AMMI stability value (ASV) of 15 Genotypes for cane and sugar yield

\section{Cane yield}

\begin{tabular}{|c|c|c|c|c|}
\hline Genotype & Mean & IPCAg1 & IPCAg2 & ASV \\
\hline $\mathrm{F}-150(\mathrm{G} 1)$ & 52.44 & 0.55 & -0.07 & 1.48 \\
\hline G.2016-168 (G2) & 53.42 & 1.37 & 0.83 & 3.77 \\
\hline G.2016-158 (G3) & 53.75 & 3.71 & -2.12 & 10.19 \\
\hline G.2016-74 (G4) & 50.12 & 0.51 & -4.17 & 4.40 \\
\hline G.2016-62 (G5) & 50.90 & 3.43 & 2.38 & 9.53 \\
\hline G.2016-99 (G6) & 53.71 & 1.82 & 0.26 & 4.91 \\
\hline G.2016-129 (G7) & 55.76 & 0.59 & 0.44 & 1.64 \\
\hline G.2016-128 (G8) & 49.45 & -0.58 & 1.62 & 2.26 \\
\hline G.2016-95 (G9) & 47.73 & -0.05 & 0.52 & 0.54 \\
\hline G.2009-11 (G10) & 54.42 & -1.20 & -1.54 & 3.58 \\
\hline K.81113 (G11) & 44.77 & -2.55 & -1.45 & 7.01 \\
\hline G.99-80 (G12) & 48.29 & -3.82 & 1.08 & 10.32 \\
\hline G.2005-47 (G13) & 55.88 & -2.26 & -0.05 & 6.08 \\
\hline G.2000-5 (G14) & 53.21 & 0.78 & 1.50 & 2.58 \\
\hline G.T.54-9 (G15) & 59.81 & -2.29 & 0.76 & 6.21 \\
\hline \multicolumn{5}{|l|}{ Sugar yield } \\
\hline $\mathrm{F}-150$ (G1) & 6.54 & 0.31 & 0.18 & 0.56 \\
\hline G.2016-168 (G2) & 6.71 & 0.30 & 0.50 & 0.72 \\
\hline G.2016-158 (G3) & 6.10 & 0.92 & -0.44 & 1.66 \\
\hline G.2016-74 (G4) & 5.72 & 0.50 & -1.67 & 1.89 \\
\hline G.2016-62 (G5) & 5.03 & 0.87 & 0.65 & 1.64 \\
\hline G.2016-99 (G6) & 6.12 & 0.70 & 0.21 & 1.23 \\
\hline G.2016-129 (G7) & 6.84 & -0.28 & 0.15 & 0.51 \\
\hline G.2016-128 (G8) & 5.97 & -0.01 & 0.47 & 0.47 \\
\hline G.2016-95 (G9) & 6.03 & -0.01 & 0.57 & 0.57 \\
\hline G.2009-11 (G10) & 5.62 & 0.07 & -0.39 & 0.41 \\
\hline
\end{tabular}




\begin{tabular}{lllll} 
K.81113 (G11) & 5.24 & -0.70 & -0.86 & 1.49 \\
\hline G.99-80 (G12) & 6.02 & -1.56 & 0.37 & 2.72 \\
\hline G.2005-47 (G13) & 6.59 & -0.43 & -0.05 & 0.74 \\
\hline G.2000-5 (G14) & 5.85 & 0.48 & 0.46 & 0.96 \\
\hline G.T.54-9 (G15) & 6.77 & -1.17 & -0.13 & 2.03
\end{tabular}

\section{Stability measurements and cultivar superiority index}

The sugarcane genotypes were ranked according to their superiority indices, cane and sugar yield and stability measures over the seven environments (Tables $7 \& 8$ ). Sugarcane genotypes exhibited variances in their means superiority and stability values. Cultivar superiority index varied from 69 to $\mathbf{3 7 8 . 1 0}$. GT54-9 showed the highest mean cane yield, and was regarded as greatest superior and stable genotype with a superiority index of 69 and stability values of 123.7. By contrast, G.2016-129 genotype recorded the highest mean sugar yield, and was regarded as maximum superior and stable genotype with a superiority index of 0.66 and stability values of 0.46. GT54-9 ranked second in terms of superiority index in sugar yield however its cane yield was the highest mean. 
Table 7. Cane yield, cultivar superiority index and mean rankings of the15 selected genotypes

\begin{tabular}{|c|c|c|c|c|c|}
\hline Code & Genotype & $\begin{array}{l}\text { Cane yield mean } \\
\text { (t/acre) }\end{array}$ & $\begin{array}{l}\text { Cultivar Superiority } \\
\text { index }\end{array}$ & $\begin{array}{l}\text { Mean } \\
\text { ranks }\end{array}$ & $\begin{array}{l}\text { Static } \\
\text { stability }\end{array}$ \\
\hline G15 & G.T.54-9 & 59.40 & 69.00 & 4.43 & 123.7 \\
\hline G7 & $\begin{array}{l}\text { G.2016- } \\
129\end{array}$ & 56.50 & 110.70 & 5.29 & 33.7 \\
\hline G13 & G.2005-47 & 55.90 & 140.90 & 5.57 & 34.5 \\
\hline G2 & $\begin{array}{l}\text { G.2016- } \\
168\end{array}$ & 53.43 & 148.50 & 7.29 & 108.7 \\
\hline G1 & $\mathrm{F}-150$ & 52.46 & 151.50 & 8.00 & 111.6 \\
\hline G6 & G.2016-99 & 53.76 & 184.40 & 7.43 & 109 \\
\hline G10 & G.2009-11 & 54.42 & 185.10 & 6.43 & 25 \\
\hline G14 & G.2000-5 & 53.23 & 193.30 & 7.29 & 90.1 \\
\hline G3 & $\begin{array}{l}\text { G.2016- } \\
158\end{array}$ & 53.76 & 219.00 & 7.29 & 280.7 \\
\hline G8 & $\begin{array}{l}\text { G.2016- } \\
128\end{array}$ & 49.47 & 230.80 & 10.29 & 63.9 \\
\hline G9 & G.2016-95 & 47.70 & 234.30 & 11.93 & 71.1 \\
\hline G4 & G.2016-74 & 50.14 & 243.70 & 9.14 & 122.6 \\
\hline G12 & G.99-80 & 48.34 & 297.10 & 9.86 & 196.4 \\
\hline G5 & G.2016-62 & 50.99 & 302.40 & 8.50 & 275.2 \\
\hline G11 & K.81113 & 44.81 & 378.10 & 11.29 & 37.6 \\
\hline
\end{tabular}


Table 8. Sugar yield, cultivar superiority index and mean rankings of the15 selected genotypes

\begin{tabular}{|c|c|c|c|c|c|}
\hline Code & Genotype & $\begin{array}{l}\text { Cane yield mean } \\
\text { (t/acre) }\end{array}$ & $\begin{array}{l}\text { Cultivar Superiority } \\
\text { index }\end{array}$ & $\begin{array}{l}\text { Mean } \\
\text { ranks }\end{array}$ & $\begin{array}{l}\text { Static } \\
\text { stability }\end{array}$ \\
\hline G7 & $\begin{array}{l}\text { G.2016- } \\
129\end{array}$ & 6.85 & 0.66 & 4.71 & 0.46 \\
\hline G15 & G.T.54-9 & 6.75 & 0.87 & 6.86 & 2.03 \\
\hline G2 & $\begin{array}{l}\text { G.2016- } \\
168\end{array}$ & 6.71 & 1.17 & 5.43 & 1.30 \\
\hline G13 & G.2005-47 & 6.60 & 1.20 & 5.29 & 0.33 \\
\hline G1 & $F-150$ & 6.54 & 1.59 & 6.86 & 1.25 \\
\hline G9 & G.2016-95 & 6.04 & 1.87 & 9.29 & 1.37 \\
\hline G8 & $\begin{array}{l}\text { G.2016- } \\
128\end{array}$ & 5.92 & 2.14 & 9.71 & 0.62 \\
\hline G6 & G.2016-99 & 6.13 & 2.46 & 7.79 & 1.04 \\
\hline G12 & G.99-80 & 6.02 & 2.71 & 8.43 & 3.66 \\
\hline G3 & $\begin{array}{l}\text { G.2016- } \\
158\end{array}$ & 6.15 & 2.88 & 7.57 & 1.73 \\
\hline G14 & G.2000-5 & 5.86 & 3.26 & 8.50 & 1.47 \\
\hline G10 & G.2009-11 & 5.63 & 3.40 & 9.57 & 0.68 \\
\hline G11 & K.81113 & 5.25 & 4.35 & 10.57 & 0.89 \\
\hline G4 & G.2016-74 & 5.63 & 4.53 & 8.71 & 2.43 \\
\hline G5 & G.2016-62 & 5.18 & 4.92 & 10.71 & 1.70 \\
\hline
\end{tabular}

\section{GGE biplot: genotypic discriminating ability and representativeness of the studied environments}

The GGE -biplot method showed that the PC1 and PC2 could explain $65.98 \%$ and $64.11 \%$ of total GEI variation for cane and sugar yields, respectively (Figs. 3, 4). Stable varieties and environments with small IPCA-1 and IPCA-2 scores are close the origin of the GGE biplot graph (22). Which-won-where GGE-biplot charts are separated by an equality line into sectors in which dissimilar mega environments can be noticed $(22,23)$. In this experiment, the equality line divided the studied environments into six megaenvironments for cane yield and four mega- environments for sugar yields (Figs. 2, 3, 4). For cane yields, the first mega environment consisted of E1 and E4 (Fig. 3), while the first mega environment for sugar yields included E1, E2 and E5 (Fig. 4). Fig. 3 and 4 help visualize the distance between each environment and the perfect environment, "model studied environment", which is at the middle of the concentric 
circles. Therefore, E1 and E4 for cane yield and E1, E2 and E5 for sugar yield, respectively were the greatest representative environment and had the maximum ability for discriminating varieties with respect to cane and sugar yields.

The vertex clone connected by the polygon in Fig. 5 were G14 and G7 for cane yield (Fig 5a). Additionally, G7 (G2016-129) was the vertex clone for sugar yield (Fig. 5b). The vertex clones were those extreme from the origin of the GGE biplot, signifying that these were either the best performers in terms of sugar yield in all or some of the environments based on their direction from origin (24).

\section{Discussion}

Fifteen sugarcane genotypes were evaluated for cane and sugar yield potential and stability in this study. These involved fourteen elite breeding lines at the final selection stages of sugarcane clones were used in this study developed by Sugar Crop Research and one check variety GT54-9. These clones are highly representative products of the sugarcane breeding program efforts in Egypt. As well, seven pilot test environments were selected from the all sugarcane production zones for evaluation and demonstration purposes. Hence, the results of these trials are of significance in guiding the selection and recommendation of superior sugarcane varieties and more stable in Egypt. Five clones, namely, G7 (G.2016-129), G15 (G.T.54-9), G2 (G.2016-168), G13 (G.2005-47) and G1 (F-150) produced both high sugar and cane yields as were predicted by the GGE and AMMI biplots models

One clone, G7 (G.2016-129) produced relatively high sugar yield, on the other hand lower cane yield compared to the commercial variety GT54-9.

Then, three clones G6 (G.2016-99) G10 (G.2009-11) and G14(G.2000-5) gave Cultivar Superiority index for relatively high cane yields, but lower Cultivar Superiority index for sugar yields. The clone G7 (G.2016129) had sugar yield and Cultivar Superiority index for sugar yield exceeding that of GT54-9, and hence was recommended for planting using a reasonable distribution of sugarcane varieties based on local conditions. Because of local conditions in Egypt, an elite sugarcane variety would have high and stable yield and would adapt to a wide range of environments. In the present study, only one clone G7 (G.2016129), fit that definition by producing higher and more stable sugar yield than the commercial variety GT $54-9$.

GGE-biplot and AMMI methods are able to estimate the weight of the environments, the genotypes and G $x E$ using a value that estimate variety stability in all environments taking into account the cane and sugar yield. The observation and analysis of $\mathrm{G} \times \mathrm{E}$ in different-environment cane and sugar yield trials is very important for selection, evaluation and recommendation of crop varieties. Stability measurements, AMMI; and GGE-biplot method were beneficial to determine the ideal genotypes for multi -environments. The AMMI methods are commonly used in breeding program of the most popular crops such as rice (25) maize $(26 ; 27)$, wheat $(28)$ and sugar beet $(29 ; 30)$ 
At the side of multivariate analyses, the ASV (AMMI stability value) supports selection of stable varieties in the AMMI Method. Varieties with lowest ASV are stable (. Therefore, the results of this study exposed that G9 (G.2016-95), G1(F-150) and G7(G.2016-129) with lowest ASV for cane yield by contrast, G10, G8(G.2016-128), G1 and G9 (G.2016-95) with lowest ASV for sugar yield, were stable clones for cane and sugar yields, respectively. Similar results were found in a study on sugar beet (31).

\section{Conclusion}

Five clones, namely, G.2016-129, G.T.54-9, G.2016-168, G.2005-47 and F-150 produced both high sugar and cane yields. One clone, G.2016-129 produced relatively high sugar yield, on the other hand lower cane yield compared to the commercial variety GT54-9. Three clones, G.2016-99, G.2009-11 and G.2000-5 gave a cultivar superiority index for relatively high cane yields, but lower cultivar Superiority index for sugar yields.

\section{Declarations}

\section{Conflict of interest}

The authors declare that they have no conflict of interest.

\section{References}

1. Mehareb, E. M. A A. M. A. El-Shafai and F. M. AboElenen Fouz. History and Current Status of Sugarcane Breeding in Egypt, S.I . : History of sugarcane breeding and molecular genetics. 2021, 1-5 .

2. Smith, Alison Barbara. Joanne K. Stringer Xianming Wei . Brian R. Cullis . Varietal selection for perennial crops where data relate to multiple harvests from a series of field trials. 2007, 157:253266

3. Wolde L, Keno T, Tadesse B, Bogale G, Abebe B. Megaenvironment targeting of maize varieties using AMMI and GGE-biplot analysis in Ethiopia. Eth J Agric Sci. 2018, 28:65-84.

4. Huehn M. Non-parametric measures of phenotypic stability. Part 1: theory. Euphytica. 1990, 47:189194.

5. Lin CS, Binns MR. A superiority measure of cultivar performance for cultivar 9 location data. Can J Plant Sci.1988, 68:193-198.

6. Gauch H.G . Statistical analysis of yield trials by AMMI and GGE. Crop Sci. 200646:1488-1500.

7. Gauch HG, Piepho HP, Annicchiarico P. Statistical analysis of yield trials by AMMI and GGE: further considerations. Crop Sci. 2008, 48:866-889.

8. Yan W, Hunt L, Sheng Q, Szlavnics Z . Cultivar evaluation and mega-environment investigation based on the GGE-biplot. Crop Sci. 2000, 40:597-605.

9. Yan W, Tinker N.A. Biplot analysis of multi-environment trial data: principles and applications. Can J Plant Sci.2006,.86(3):623-645. 
10. Kaya Y, Akc, ura M, Taner S () GGE-biplot analysis of multi-environment yield trials in bread wheat. Turk J Agric For 2006,30:325-337.

11. Yan, W.; Kang, M.S.; Ma, B.; Woods, S.; Cornelius, P.L. GGE biplot vs. AMMI analysis of genotype-byenvironment data. Crop Sci. 2007, 47, 643-655.

12. Yan W, Holland JB . A heritability-adjusted GGE biplot for test environment evaluation. Euphytica. 2010, 171:355-369

13. Gauch HG, Zobel RW. Identifying mega-environments and targeting genotypes. Crop Sci 1997,37:311-326

14. Gomez, K. A. and Gomez, A. A. Statistical Procedures for agricultural Research. 2nd Edn., John Wiley and Sons Inc., New York USA1984, pp. 95-109.

15. Akcura, M.; Kaya, Y. Nonparametric stability methods for interpreting genotype by environment interaction of bread wheat genotypes (Triticum aestivum L.). Genet. Mol. Biol. 2008, 31, 906-913.

16. Romagosa, I.; Fox, P.N. Genotype _ environment interaction and adaptation. In Plant Breeding; Springer: Dordrecht, The Netherlands, 1993; pp. 373-390, ISBN 9401046654.

17. Purchase, J.L. (1997). Parametric analysis to describe $G \times E$ interaction and stability in winter wheat. $\mathrm{PhD}$ thesis. Department of Agronomy, Faculty of Agriculture, University of the Orange Free State, Bloemfonten, South Africa.

18. Purchase JL, Hatting H, Van Deventer CS (2000) Genotype x environment interaction of winter wheat (T. aestivum) in South Africa: stability analysis of yield performance. S Afr J Plant Soil 17:101-107

19. Naroui Rad MR, Abdul KadirM, Rafii YM, Hawa ZEJ, Naghavi MR, Ahmadi A (2013) Genotype $x$ environment interaction by AMMI and GGE biplot analysis in three consecutive generations of wheat (Triticum aestivum) under normal and drought stress conditions. Aust J Crop Sci 7:956-961

20. Elbasyoni, S. (2018). Performance and Stability of Commercial Wheat Cultivars under Terminal Heat Stress. Agronomy, 8- 37.

21. Al-Naggar, A.M.M., M.M. Shafik and R.Y.M. Musa Ammi and gge biplot analyses for yield stability of nineteen maize genotypes under different nitrogen and irrigation levels. Plant Archives Volume 20 No. 2, 2020 pp. 4431-4443

22. Yan W, Tinker NA (2005) An integrated biplot analysis system for displaying, interpreting, and exploring genotype by environment interactions. Crop Sci 45:1004-1016. https://doi.org/10.2135/cropsci2004.0076

23. Yan W, Tinker AN (2006) Biplot analysis of multi-environment trial data: Principles and applications. Canad J Plant Sci. 86:623-664. https://doi.org/10.4141/P05-169

24. Tollo, Joyce Awino. Pascal P. Okwiri Ojwang . Rael Karimi .Joseph Juma Mafurah . Henry Sila Nzioki. Genotype-by-environment interaction and stability of resistance in mungbean landraces against common bacterial blight across semi-arid environments, Euphytica (2020) 216:175

25. Inabangan-Asilo MA, Swamy BPM, Amparado AF, Descalsota- Empleo GIL, Arocena EC, Reinke R (2019) Stability and G 9 E analysis of zinc-biofortified rice genotypes evaluated in diverse 
environments. Euphytica 215:61

26. Bernardo Ju'nior LAY, da Silva CP, de Oliveira LA, Nuvunga JJ, Pires LPM, Von Pinho RG, Balestre M (2018) AMMI bayesian models to study stability and adaptability in maize. Agron J 110(5):17651776

27. Bocianowski J, Nowosad K, Tomkowiak A (2019) Genotype-environment interaction for seed yield of maize hybrids and lines using the AMMI model. Maydica 64:M 13

28. Sardouei-Nasab S, Mohammadi-Nejad G, Nakhoda B (2019) Yield stability in bread wheat germplasm across drought stress and non-stress conditions. Agron J 111(1):175-181

29. Mehareb E.M., H.M.Y. EL-Bakary and Fouz. F.M. Abo elenen. Comprehensive evaluation of sugar beet genotypes for yield and relative traits by multivariate analysis. SVU-International Journal of Agricultural Science. Volume 3 Issue (1) pp.: 2021,96-111.

30. Bassiony, Noran A. Eman, M., Abdel Fatah, M., Khadijah, I. El-Gabry M., Mehareb, E.M. (2020) 'Yield performance and AMMI biplot analysis of some sugar beet varieties under olive mill waste treatments at multi environmental conditions', Direct Res. Agric. Food Sci.Vol.8 (2),pp. 48-61.

31. Hassani, M. Bahram Heidari . Ali Dadkhodaie . Piergiorgio Stevanato. Genotype by environment interaction components underlying variations in root, sugar and white sugar yield in sugar beet (Beta vulgaris L.). Euphytica, 2018,214:79.

\section{Figures}


Cane_Yield: AMMI biplot (symmetric scaling)

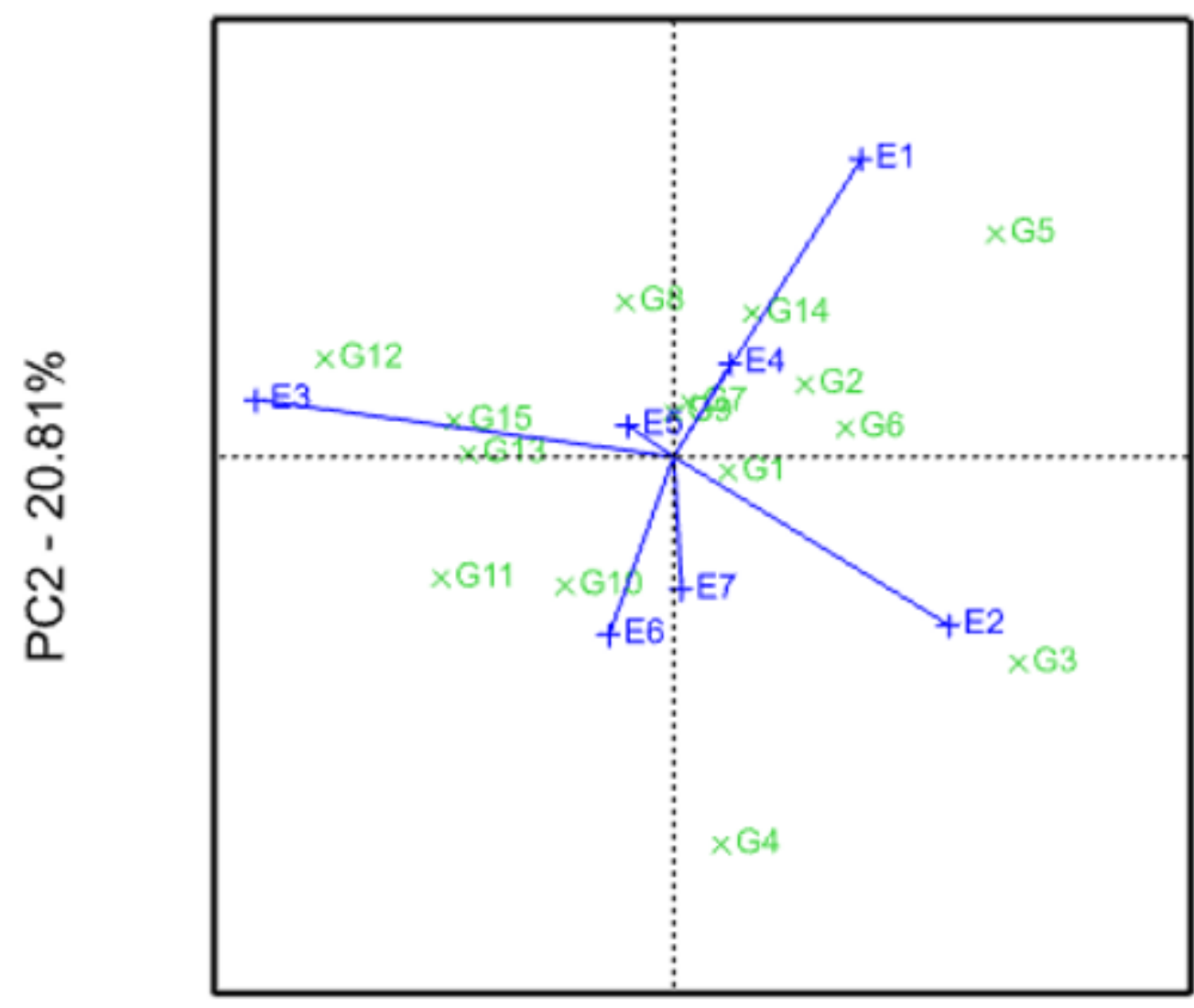

$$
\text { PC1 }-56.11 \%
$$

$\begin{array}{ll}\times & \text { Genotype scores } \\ +\quad & \text { Environment scores } \\ \text { Vectors } & \end{array}$

Figure 1

AMMI biplot presenting cane yield for 15 sugarcane genotypes. 
Sugar_yield: AMMI biplot (symmetric scaling)

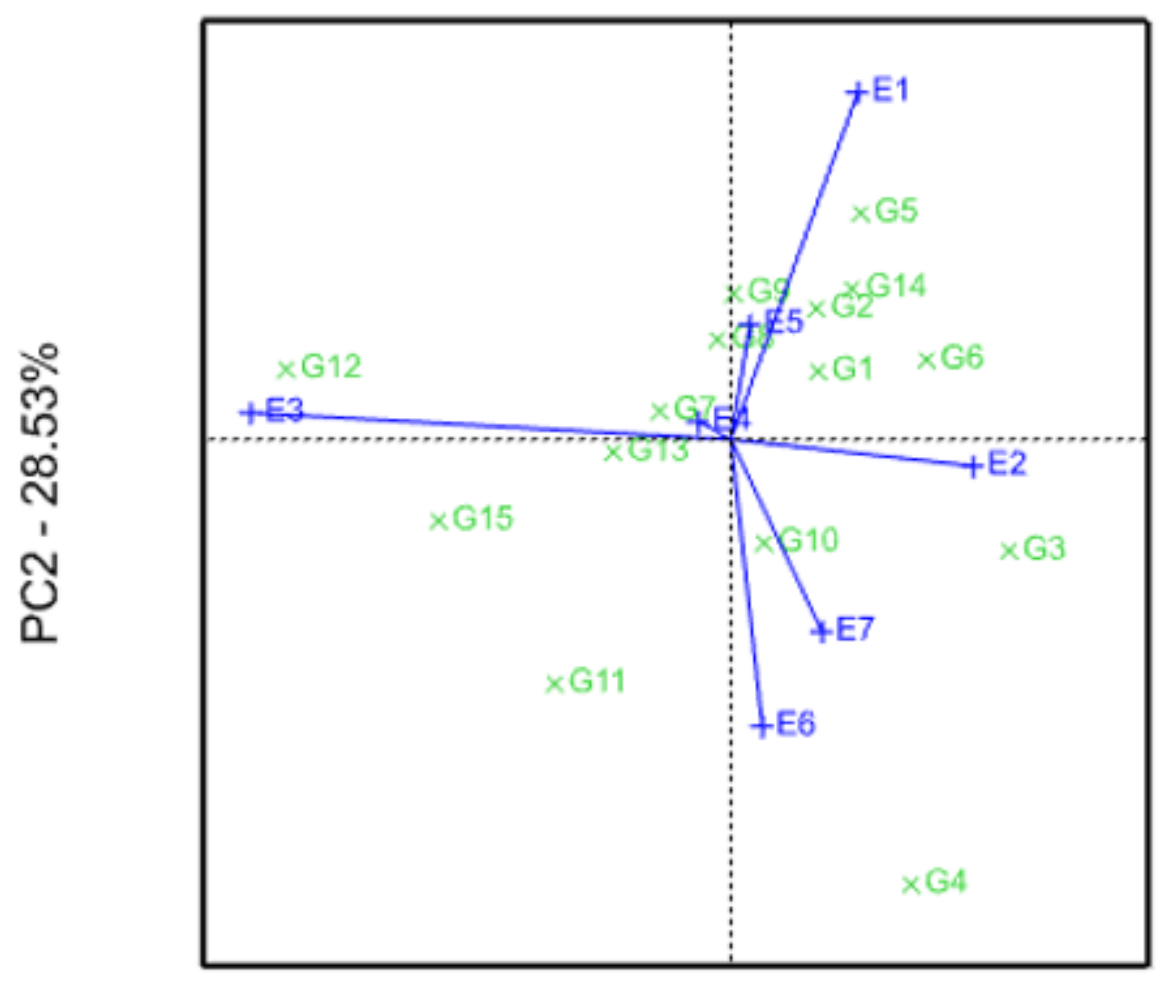

PC1 - $44.07 \%$

$\begin{array}{ll}\times & \text { Genotype scores } \\ +\quad & \text { Environment scores } \\ & \text { Vectors }\end{array}$

Figure 2

AMMI biplot presenting sugar yield for 15 sugarcane genotypes. 


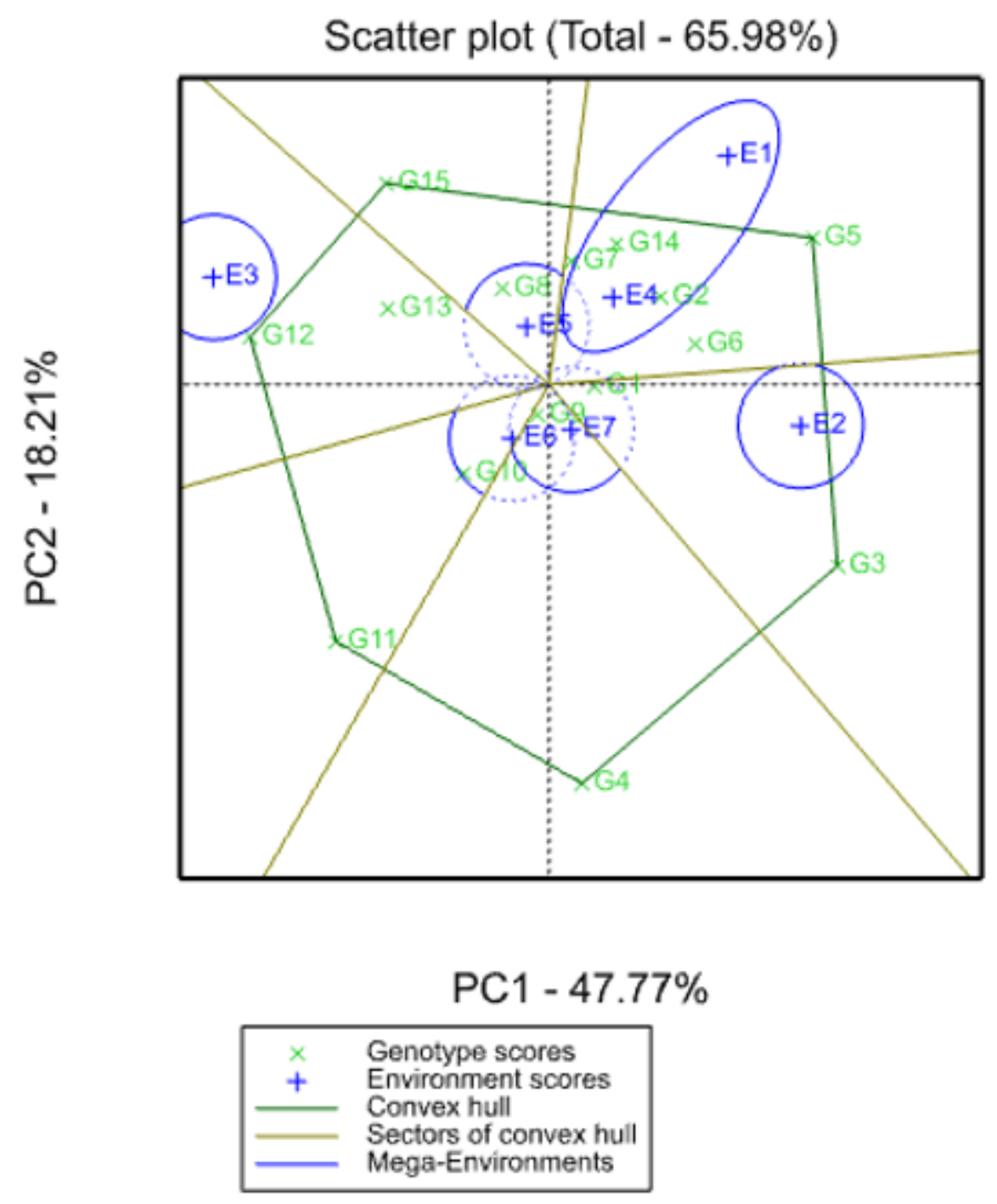

Figure 3

Which-won-where polygon view of the GGE biplot for cane yield of 15 sugarcane genotypes $(G)$ in 7 different environments (E) to show that genotype performed superlative in which environment and significant mega environment. 


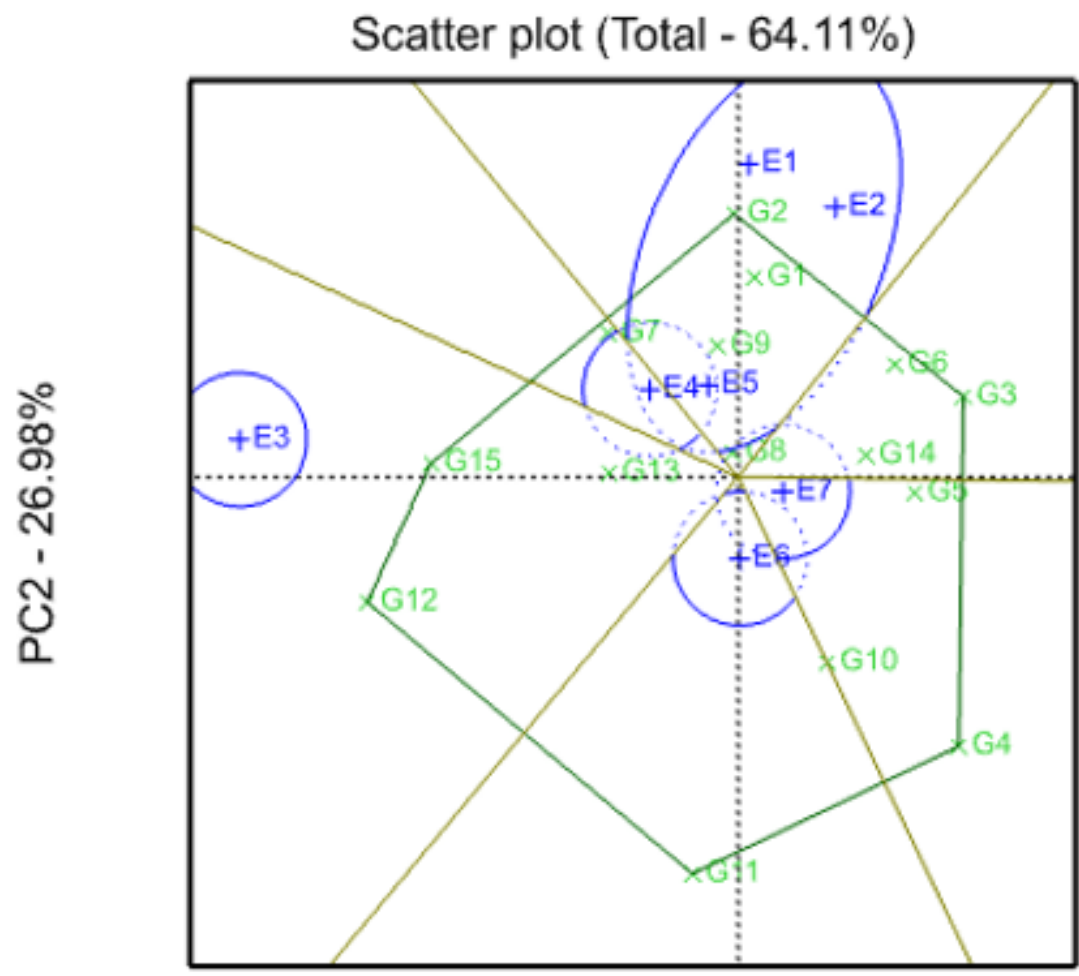

PC1 $-37.13 \%$

$\begin{array}{cl}\times & \text { Genotype scores } \\ +\quad & \text { Environment scores } \\ & \text { Convex hull } \\ & \text { Sectors of convex hull } \\ & \text { Mega-Environments }\end{array}$

\section{Figure 4}

Which-won-where polygon view of the GGE biplot for sugar yield of 15 sugarcane genotypes $(G)$ in 7 different environments $(E)$ to show that genotype performed superlative in which environment and significant mega environment. 

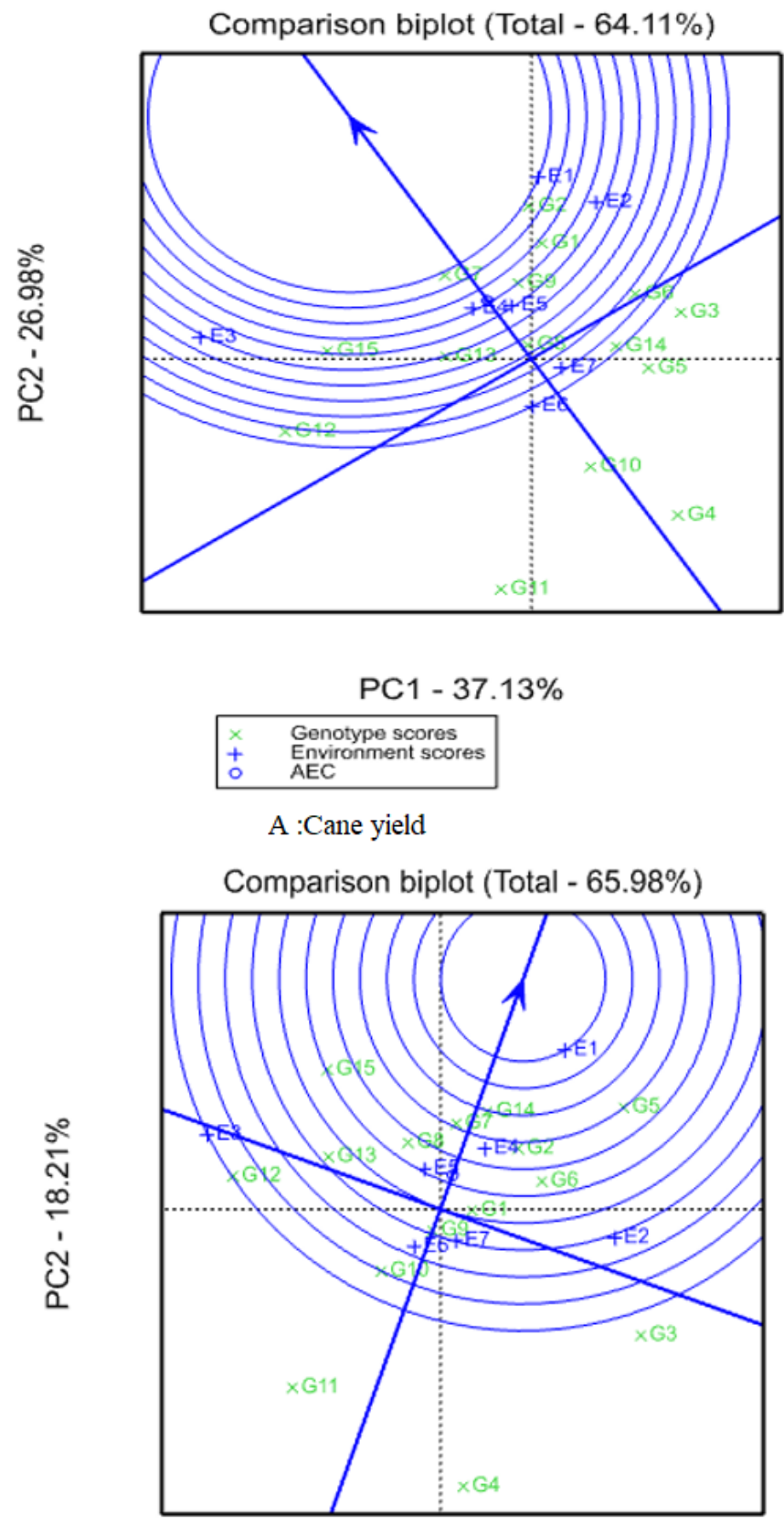

PC1 $-47.77 \%$

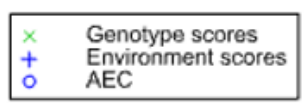

B: sugar yield

\section{Figure 5}

Genotype main effect plus genotype-by-environment (GGE) biplots of sugarcane genotypes based on cane yield (a) and sugar yield (b) in seven studied environments. , GGE biplot showing a polygon view of a scatter plot of which genotype won where. 


\section{Supplementary Files}

This is a list of supplementary files associated with this preprint. Click to download.

- Suplemntery2.docx 